\title{
Modeling study of Dana Point Harbor, California: littoral sediment transport around a semi-permeable breakwater
}

\author{
Honghai Li ${ }^{1}$ - Lihwa Lin ${ }^{1}$ - Chia-Chi Lu' ${ }^{2}$ Christopher W. Reed ${ }^{3}$. \\ Arthur T. Shak ${ }^{4}$
}

Received: 17 October 2014 / Accepted: 9 March 2015 / Published online: 2 April 2015

(C) Springer International Publishing AG (outside the USA) 2015

\begin{abstract}
Dana Point Harbor is located on the southern California coast, midway between Los Angeles and San Diego. The harbor is protected by dual semi-permeable breakwaters, the East and the West Breakwaters. The permeability of the breakwaters has been designed to promote circulation and improve water quality in the harbor. However, wave and flow actions have increased sediment movement around the West Breakwater and resulted in harbor channel infilling in recent years. To investigate the sediment transport around the porous breakwater and reduce potential dredging cost in the future, an integrated coastal wave, hydrodynamic and sediment transport numerical model was used to investigate the effect of the permeability of breakwater. First, the model was validated with the field measurements of waves, current, and water surface elevation at two ADCP gages located on the harbor side and the ocean side of the West Breakwater. Further validation in the model's capability to simulate wave flow through a porous structure was also performed with a laboratory experiment of low-crested structures under regular waves. Wave transmission, flow and sediment around the West Breakwater were calculated for 1-year period of 20092010. The calculated annual sediment rate in the inner side
\end{abstract}

$\triangle$ Honghai Li

honghai.li@usace.army.mil

1 U.S. Army Engineer Research \& Development Center, Coastal and Hydraulics Laboratory, 3909 Halls Ferry Road, Vicksburg, MS 39180-6199, USA

2 Noble Consultants Inc., 2201 Dupont Drive, Suite 620, Irvine, CA 92612, USA

3 Reed \& Reed Consulting, LLC, 1400 Village Square Blvd, Unit 3-146, Tallahassee, FL 32312, USA

4 U.S. Army Corps of Engineers, Los Angeles District, 915 Wilshire Blvd., Los Angeles, CA 90017, USA of breakwater was comparable to the sediment accumulation rate available from historical dredging records.

Keywords Coastal modeling $\cdot$ Hydrodynamics $\cdot$ Sediment transport . Permeable breakwater . Wave transmission . Flow and sediment seepage $\cdot$ Current

\section{Introduction}

Breakwaters are built to protect coastal infrastructure and properties. A properly designed breakwater can reduce shoreline change and beach erosion from waves, tide, and storms. Among different types of breakwaters, rubble-mound breakwaters comprising of irregular, rough stones or concrete armor units usually contain high voids. While the voids permit breakwaters to absorb and dissipate wave energy, they provide pathways for flow and sediment to move through, which may destabilize breakwaters, cause sediment accumulation in navigation channel, and increase harbor maintenance cost (Simpson et al. 1990).

Various researches and studies focused on wave transmission and flow through porous structures (d'Angremond et al. 1996; Garcia et al. 2004; Lara et al. 2006; Tsai et al. 2006; Sidiropoulou et al. 2007). In coastal modeling applications, rubble-mound breakwaters are often treated as solid and impermeable structures. In reality, both the volume of water and quantity of sediment transport through porous structures can alter flow pattern, induce morphological changes around the structures, and result in significant beach erosion and shoreline change in areas protected by structures (TM 5-622/MO-104/AFM 91-34 1978). Because the nature of permeability in rubble-mound breakwaters is significant in hydrodynamics and sediment transport, it is critical to incorporate the mechanism in coastal numerical models. 
The implementation of structure permeability in the Coastal Modeling System (CMS) is applied at Dana Point Harbor on the southern California coast (Li et al. 2011; Lu et al. 2014). Following the general introduction above, Sect. 2 presents the background information on study area. Section 3 describes the data collected and assembled. In Sect. 4, the method is presented in the model implementation of rubble-mound permeability. Section 5 presents and discusses model results and the comparisons with field data. Section 6 is a summary.

\section{Study area}

Dana Point Harbor is located on the US Pacific coast, $65 \mathrm{~km}$ (40 miles) southeast of Los Angeles, CA. The manmade harbor is protected from ocean swells and waves by a pair of riprapped breakwaters constructed in the late 1960s. The breakwaters consist of a long shore-parallel West Breakwater of $1676 \mathrm{~m}(5500 \mathrm{ft})$ and a shore-normal East Breakwater

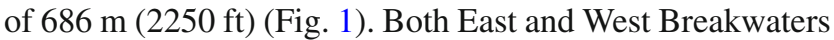
were comprised of multiple layers of riprap stones, which include core stones, $2722 \mathrm{~kg}$ (3-ton), $5443 \mathrm{~kg}$ (6-ton), and $10,886 \mathrm{~kg}$ (12-ton) stones in the outer layers. Those larger riprap stones correspond to a mean spherical stone diameter of $1.3,1.6$ and $2.0 \mathrm{~m}$, respectively, if assuming the stonespecific weight is $2650 \mathrm{~kg} / \mathrm{m}^{3}$. Small voids were left intentionally during stone placement to allow currents partially flowing through the breakwaters, thereby promoting harbor circulation and self-flushing capability (Lu et al. 2014).
A comprehensive condition survey at Dana Point Harbor reported that the East Breakwater had remained in excellent design condition and functioned well as a protective device for the harbor operation (USACE-LAD 1991). No significant amount of sand has been found to pass through the East Breakwater. Only at the northwest end of the West Breakwater the material accumulation has been found on the harbor side and maintenance dredging required in about every 10 years (California Coastal Commission 2008). Therefore, to simulate wave transmission, and flow and sediment passage through a structure, this study focuses on the West Breakwater. The permeability of structure is formulated in the CMS.

Figure 2 shows the CMS domain, approximately $5 \mathrm{~km}$ alongshore and $4 \mathrm{~km}$ offshore, which is discretized into variable rectangular grid surrounding Dana Point Harbor with smaller grid cells of $5 \times 5 \mathrm{~m}$ in the harbor and around breakwaters. The water depth ranges from $1 \mathrm{~m}$ at Baby Beach to $9 \mathrm{~m}$ at the harbor entrance channel inside the marina, and increases to more than $10 \mathrm{~m}$ outside the West Breakwater. The model offshore area, open to the Pacific Ocean, deepens to $200 \mathrm{~m}$.

\section{Data}

Bathymetry data are needed to set up the CMS grid. A hydrographic and light detection and ranging (LiDAR) survey was conducted in October 20-24, 2009 (Fugro West 2010). A multi-beam sonar was used to collect bathymetric data and
Fig. 1 Dana Point Harbor and surroundings; the zoomed-in area is the CMS domain

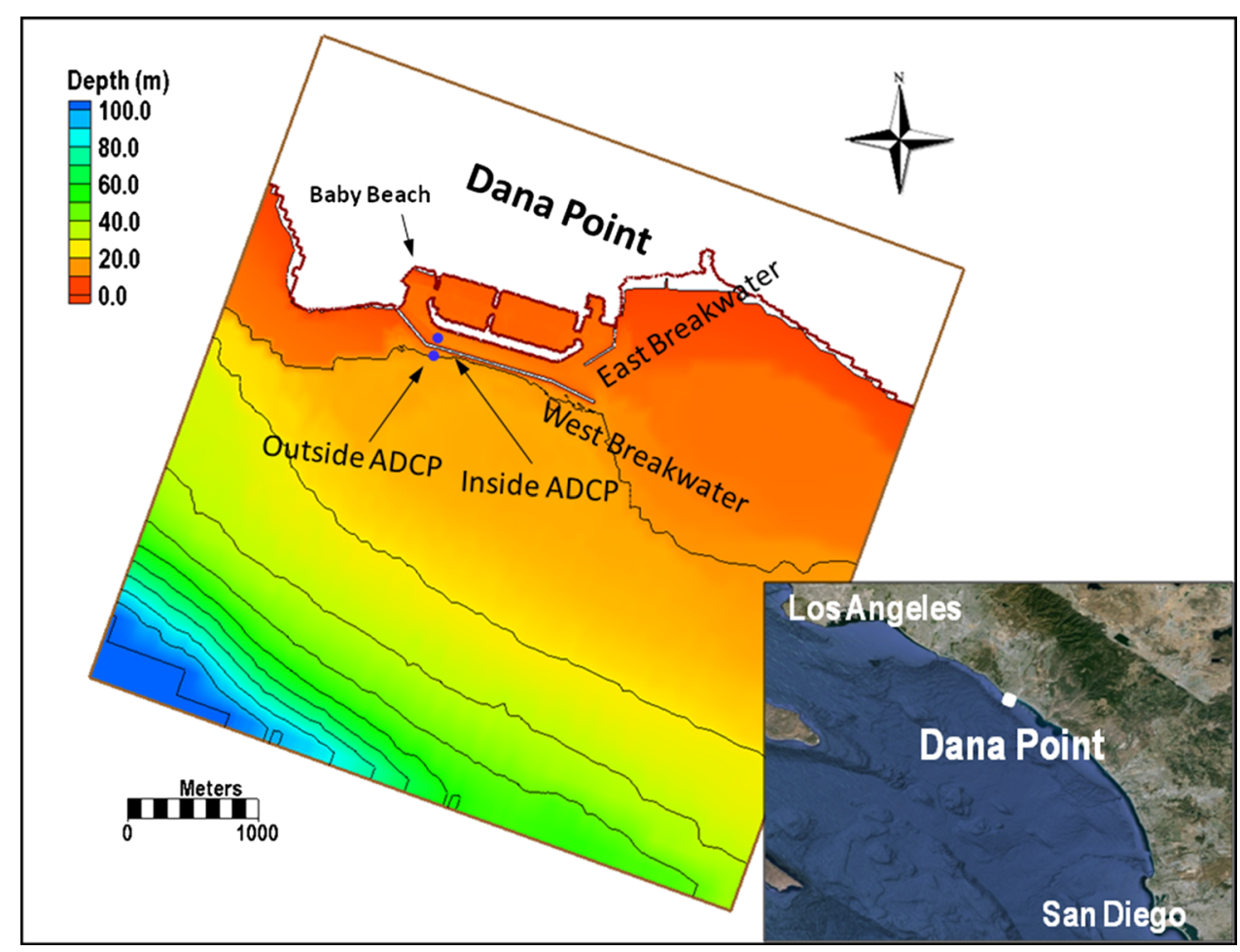




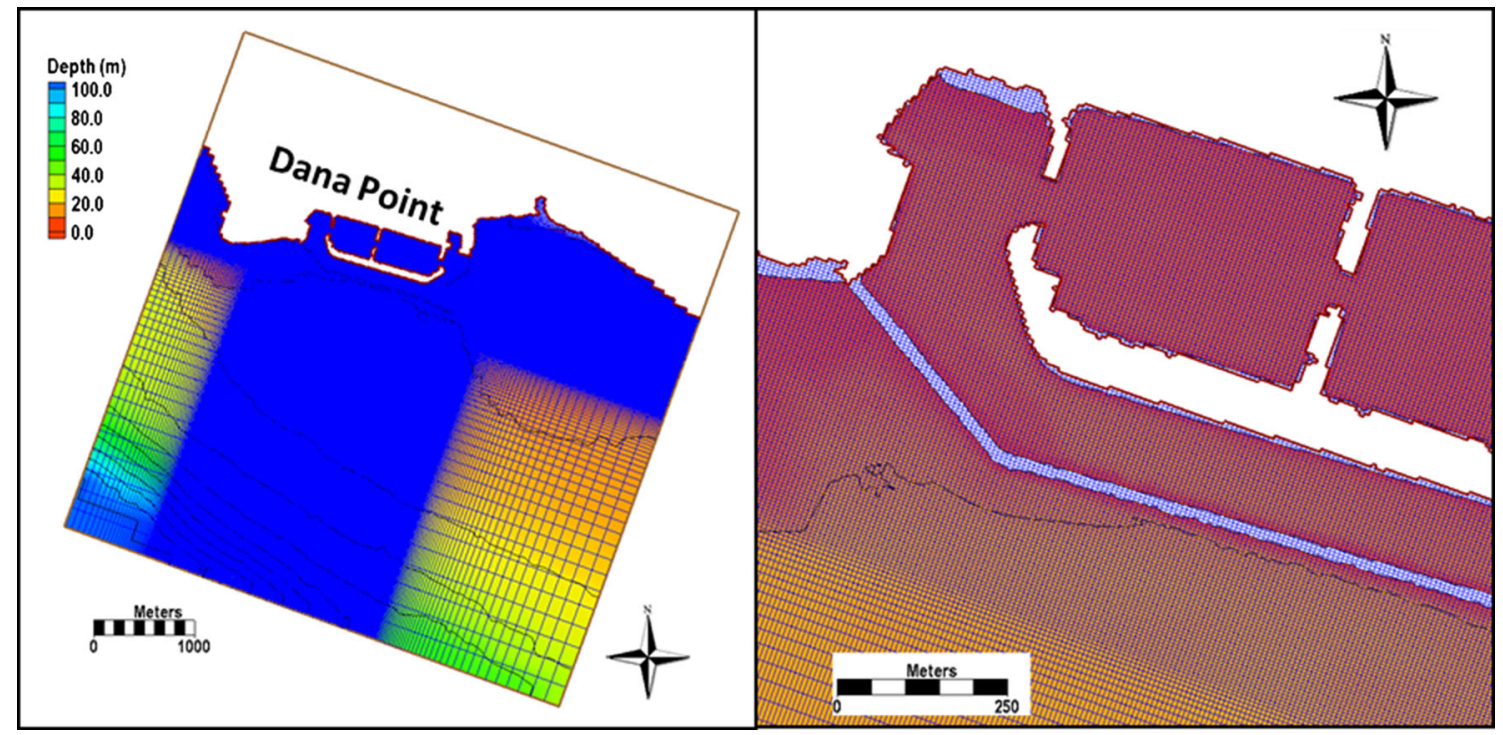

Fig. 2 The CMS model grid

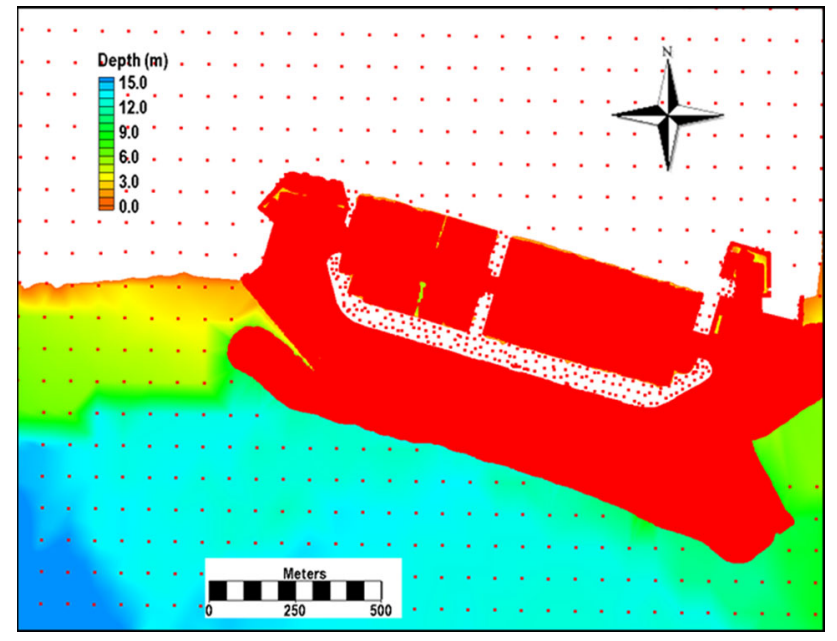

Fig. 3 Water depth contours, and scatter points of the hydrographic and LiDAR survey (densely sampled area) and the GEODAS dataset (coarsely gridded area)

a laser system for the breakwater conditions above the water level. The data collection system has a horizontal accuracy of $0.15 \mathrm{~m}(0.5 \mathrm{ft})$ and vertical accuracy of $0.07 \mathrm{~m}(0.25 \mathrm{ft})$, which presents detailed bathymetric features and provides high-quality depth information in the marina and around the harbor. The bathymetry data in the rest of the model domain, not covered by the survey, were extracted from GEOphysical DAta System (GEODAS) database (NGDC 2009). Figure 3 shows water depth contours and scatter points of the two datasets. The densely sampled area corresponds to the hydrographic and LiDAR survey and the coarsely gridded area to the GEODAS database. The depth contours reveal jumpy depth transitions between the two datasets in the nearshore area.
Two ADCP gages were deployed at the locations inside and outside the West Breakwater (Fig. 1; Fugro West 2010) from November 2009 through January 2010. Waves and water level were measured at the outside gage while only current was measured at the inside gage. Because of instrument malfunction, only 6 days of data were recovered from the outside ADCP.

Sediment seepage through the West Breakwater has resulted in navigation channel infilling during the last 2030 years. Since 1990, three maintenance dredges have been conducted to remove fine sand material that passed through and deposited on the harbor side of the West Breakwater. The dredged volumes inside the West Breakwater are approximately $19,115 \mathrm{~m}^{3}$ (25,000 cy), 27,143 $\mathrm{m}^{3}$ (35,500 cy), and $41,288 \mathrm{~m}^{3}$ (54,000 cy), respectively, in 1990, 1999, and 2009 (County of Orange 1990; California Coastal Commission 1999, 2008).

The driving forces for the CMS include water surface elevation (WSE), wind, and waves. Hourly water surface elevation was obtained from a NOAA tide gage (9410660, Los Angeles, CA, USA) close to the Dana Point Harbor (http:// tidesandcurrents.noaa.gov/waterlevels.html?id $=9410660$, accessed 18 June 2014$)\left(33^{\circ} 43.2^{\prime} \mathrm{N}, 118^{\circ} 16.4^{\prime} \mathrm{W}\right)$. Corresponding to the period of the ADCP survey, a 30-day tide record from November 18 to December 17, 2009 is shown in Fig. 4 and it indicates a mixed, predominately semi-diurnal tidal regime surrounding the study area. The mean tidal range (mean high water-mean low water) is $1.16 \mathrm{~m}$ and the maximum mean tidal range (mean higher high water-mean lower low water) is $1.67 \mathrm{~m}$.

The Dana Point Harbor is well protected by the East and West Breakwaters from ocean waves. The rather weak circulation inside the harbor is sensitive to wind forcing. Wind 


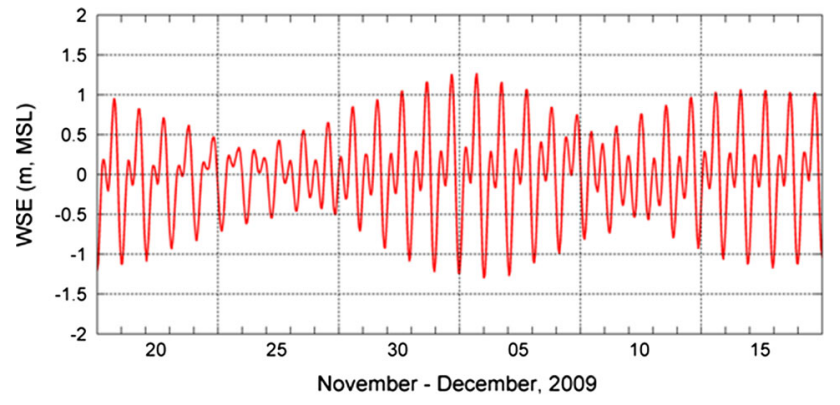

Fig. 4 Water surface elevation (WSE, m) at NOAA Los Angeles tide gage (9410660), 18 November-17 December, 2009
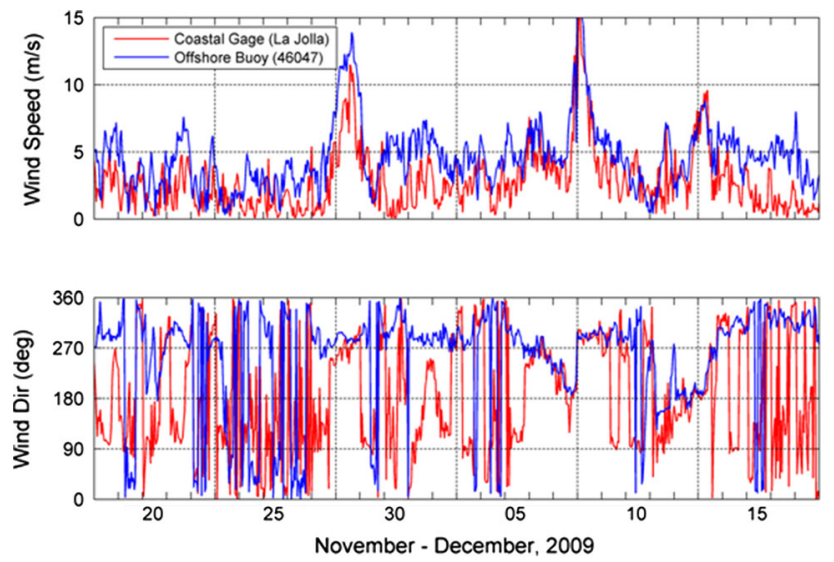

Fig. 5 Wind speed and direction at the coastal gage, NOAA La Jolla gage (9410230) and the offshore buoy, NDBC buoy 46047, November 18-December 17, 2009

data are available from an NOAA coastal station at La Jolla, CA, USA (9410230) (http://tidesandcurrents.noaa.gov/met. html?id=9410230, accessed 18 June 2014) $\left(32^{\circ} 52^{\prime} 157 \mathrm{~N}\right.$, $117^{\circ} 15.4^{\prime} \mathrm{W}$ ) and from an NDBC Buoy 46047 located approximately $200 \mathrm{~km}$ offshore (http://www.ndbc.noaa.gov/ station_page.php?station $=46047$, accessed 18 June 2014) $\left(32^{\circ} 24^{\prime} 11^{\prime \prime} \mathrm{N}, 119^{\circ} 32^{\prime} 8^{\prime \prime} \mathrm{W}\right)$. Figure 5 shows the time series of wind at the two locations during the period of November 18-December 17, 2009. The 30-day averaged wind speeds are 2.7 and $4.4 \mathrm{~m} / \mathrm{s}$ at the nearshore and offshore locations, respectively. While a dominant northwesterly wind is displayed at the buoy, the coastal wind is characterized by the diurnal cycle of the sea breeze.

Directional wave data for this study were obtained from a Coastal Data Information Program (CDIP) (http://cdip.ucsd. edu/, accessed 18 June 2014) buoy in the nearshore area of Dana Point Harbor, CDIP096 ( $\left.33^{\circ} 27^{\prime} 31^{\prime \prime} \mathrm{N}, 117^{\circ} 46^{\prime} 2^{\prime \prime} \mathrm{W}\right)$. The analysis of the 2009 wave data shows that the predominant waves at this buoy site propagate from the southsouthwest $\left(180^{\circ}-200^{\circ}\right.$ azimuth) during summer and the west-northwest $\left(270^{\circ}-280^{\circ}\right.$ azimuth) directions during winter months. The annual average wave height and peak wave period are $0.91 \mathrm{~m}$ and $13.5 \mathrm{~s}$, respectively. Large waves (sig-

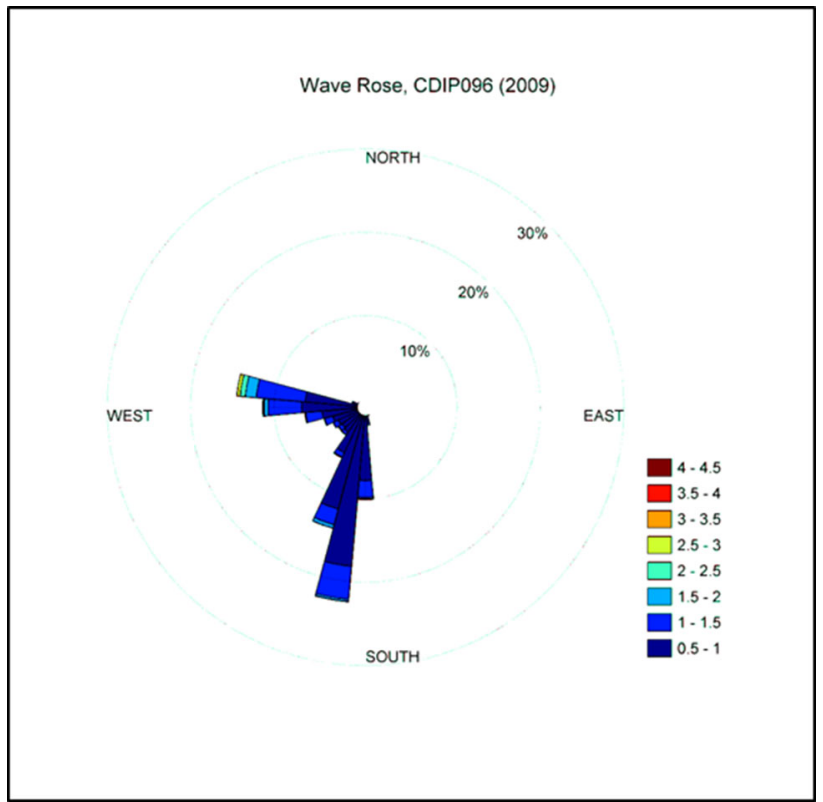

Fig. 6 Wave rose at CDIP096 for 2009

nificant wave heights $>1.5 \mathrm{~m}$ ) mostly propagate from the west-northwest and occur during winter time (Fig. 6).

\section{Methodology}

\subsection{Coastal modeling system}

The flow, wave, and sediment transport modeling is conducted using the CMS in this study. The CMS is an integrated suite of numerical models, consisting of CMS-Flow and CMS-Wave (http://cirp.usace.army.mil/wiki/CMS, accessed 27 March 2015).

CMS-Flow is a two-dimensional (2-D) finite-volume model that solves the mass conservation and shallow-water momentum equations of water motion on a nonuniform Cartesian grid (Buttolph et al. 2006; Sanchez et al. 2011a; Sanchez 2011b). Wave radiation stresses and wave parameters calculated by CMS-Wave are supplied to CMS-Flow for the flow and sediment transport calculations. Water level, current, and morphology changes are provided to CMS-Wave at user-specified intervals.

CMS-Wave is a 2-D spectral wave transformation model that solves the steady-state wave-action balance equation on a nonuniform Cartesian grid (Lin et al. 2009, 2011). The model is designed to simulate wave processes that are significant in coastal inlets, in the nearshore zone, in the vicinity of jetties and breakwaters, and in ports and harbors. These processes include wave shoaling, refraction, diffraction, reflection, wave breaking and dissipation, wavestructure and wave-current interactions, and wave generation and growth mechanisms. 
CMS-Flow and CMS-Wave can be coupled and operated through a steering module available in the Surface-water Modeling System (Aquaveo 2010). The coupled modeling system calculates time-dependent water elevation, current speed and direction, waves, sediment transport, and morphology change in coastal, estuarine, and inlet systems. For general coastal applications, the CMS can be driven by tide, wind, waves, and river flow.

\subsection{Wave transmission and flow seepage through porous structure}

The calculation of the wave transmission coefficient in the CMS is based on d'Angremond et al. (1996) and the method can be applied to both monochromatic and random waves (Lin et al. 2009). The wave transmission coefficient for permeable breakwaters is a function of the crest width, the crest freeboard, the significant wave height, the fore-slope, the incident wave steepness, and the structure porosity.

For the steady flow through a permeable structure the Forchheimer law (Forchheimer 1901) is applied and a nonlinear term is introduced to the Darcy equation:

$$
I=a U+b U^{2},
$$

where $I$ is the hydraulic gradient across porous media, $U$ describes the Darcy velocity, and coefficients $a$ and $b$ represent the laminar and turbulent components of flow resistance, respectively. Equation (1) is incorporated into the flow governing equations as the balance between a driving and a resistant forcing. The depth-averaged momentum equations in the $x$ - and $y$-directions of Cartesian coordinates can be expressed as:

$$
\begin{gathered}
\frac{\partial(D u)}{\partial t}+\frac{\partial(D u u)}{\partial x}+\frac{\partial(D u v)}{\partial y}-f D v+g D \frac{\partial D}{\partial x} \\
=\frac{\partial}{\partial x}\left(A D \frac{\partial u}{\partial x}\right)+\frac{\partial}{\partial y}\left(A D \frac{\partial u}{\partial y}\right)+\mathrm{T}_{x}+R_{x} \\
\frac{\partial(D v)}{\partial t}+\frac{\partial(D u v)}{\partial x}+\frac{\partial(D v v)}{\partial y}-f D u+g D \frac{\partial D}{\partial y} \\
=\frac{\partial}{\partial x}\left(A D \frac{\partial v}{\partial x}\right)+\frac{\partial}{\partial y}\left(A D \frac{\partial v}{\partial y}\right)+\mathrm{T}_{y}+R_{y}
\end{gathered}
$$

where $t$ is the time; $D$ is the total water depth (sum of the still water depth, $h$, and the water surface elevation, $\eta$ ); $u$ and $v$ are the depth-averaged flow velocity components in the $x$ - and $y$-directions, respectively; $g$ is the gravitational acceleration; $A$ is the horizontal diffusivity; $T_{x}$ and $T_{y}$ are the surface and bottom stresses in $x$ - and $y$-directions, respectively; $f$ is the Coriolis parameter; $R_{x}$ and $R_{y}$ are the corresponding resistant forcing for porous structures:
$R_{x}=-g D u\left(a+b \sqrt{u^{2}+v^{2}}\right)$,

and

$R_{y}=-g D v\left(a+b \sqrt{u^{2}+v^{2}}\right)$

where $a$ and $b$ are flow resistance coefficients depending on structure characteristics. The existence of structure void space requires modification of the conservation of mass equation in the permeable structure as

$\frac{\partial \eta}{\partial t}=\frac{1}{n}\left(\frac{\partial D u}{\partial x}+\frac{\partial D v}{\partial y}\right)$

where $n$ is the porosity of permeable media. Similarly the sediment mass conservation equation is revised to calculate bed elevation change considering the structure porosity:

$\frac{\partial \zeta}{\partial t}=\frac{1}{n}\left(\frac{\partial q_{x}}{\partial x}+\frac{\partial q_{y}}{\partial y}-E^{*}+D^{*}\right)$

where $\zeta$ is the bed elevation, and $q_{x}$ and $q_{y}$ are the bedload fluxes in the $x$-and $y$-directions, $E^{*}$ is the erosion flux, and $D^{*}$ is the deposition flux.

Sidiropoulou et al. (2007) reviewed various studies and proposed more accurate empirical formulations for the calculations of the flow resistance coefficients $a$ and $b$ in Eq. (1) as

$$
\begin{aligned}
& a=0.003333 d^{-1.500403} n^{0.060350} \\
& b=0.194325 d^{-1.265175} n^{-1.141417},
\end{aligned}
$$

where $d$ is the rock diameter and $n$ is the same as defined in Eq. (6).

For the implementation of structure permeability in the CMS, Reed (personal communication, 15 February 2011) designed a numerical experiment with rubble-mound rock sizes in the range of $1-3 \mathrm{~cm}$ to calculate the coefficients $a$ and $b$ in Eq. (1). He evaluated three sets of formulas of Ward (1964), Kadlec and Knight (1996) and Sidiropoulou et al. (2007). Using these formulas with a constant value of structure porosity and different rock diameters, the calculated flow seepage rates, defined as the maximum difference divided by the average flow seepage rate, can vary from 30 to $50 \%$ and the results indicate a moderate seepage sensitivity to the values of $a$ and $b$ determined by selected rock sizes.

In the present application, all three formulas were tested with a given range of structure porosity and rock diameters. The test results show the calculated sediment seepage rates through the breakwater are similar from three formulas. The results in the following analysis are obtained using Eqs. (8) and (9) for the calculation of structure permeability. 
Table 1 Simulation scenarios of waves, hydrodynamics, and sediment transport

\begin{tabular}{llc}
\hline Scenario & Period (date) & Duration (day) \\
\hline Calibration & $18-27$ November, 2009 & 10 \\
Validation & 18 November-17 December, 2009 & 30 \\
Long-term & 18 November, 2009-17 November, 2010 & 365 \\
\hline
\end{tabular}

\begin{tabular}{lllll}
\hline Experiment & Wave height $(\mathrm{m})$ & Fore-slope & Crest width $(\mathrm{m})$ & Crest freeboard $(\mathrm{m})$ \\
\hline R1F1C2 & 0.30 & $1 \mathrm{~V}: 2 \mathrm{H}$ & 1.825 & 0.07 \\
R1F2C2 & 0.30 & $1 \mathrm{~V}: 2 \mathrm{H}$ & 1.825 & 0.27 \\
\hline
\end{tabular}

Table 2 Wave height and parameters of the breakwater in the Lara et al. (2006) laboratory experiments and the CMS simulations
Table 3 Wave height $(\mathrm{m})$ comparisons between the laboratory experiments and the CMS simulations

\begin{tabular}{lllllll}
\hline Experiment & Scenario & \multicolumn{6}{l}{ Wave height (m) } \\
\cline { 3 - 7 } & & WG 3 & WG 4 & WG 5 & WG 6 & WG 7 \\
\hline R1F1C2 & Lab & 0.45 & 0.46 & 0.51 & 0.10 & 0.10 \\
& CMS & 0.51 & 0.51 & 0.51 & 0.09 & 0.09 \\
R1F2C2 & Lab & 0.47 & 0.46 & 0.51 & 0.01 & 0.01 \\
& CMS & 0.46 & 0.46 & 0.46 & 0.01 & 0.01 \\
\hline
\end{tabular}

Consistent with the CMS grid orientation, the flow direction convention is that the positive is for the east-southeast flow (the ebb current at the inside ADCP) and the negative for the west-northwest flow (the flood current at the inside ADCP).

\subsubsection{Laboratory experiment}

Further validation in the model's capability to simulate wave flow through a porous structure was performed with a laboratory experiment of low-crested structures. Garcia et al. (2004) and Lara et al. (2006) set up the original experiment with submerged and emerged structures. In this validation case, the large-scale channel experimental domain and wave conditions were used and two experiments (R1F1C2 and $\mathrm{R} 1 \mathrm{~F} 2 \mathrm{C} 2$ ) configured with emerged breakwaters in Lara et al.'s (2006) work were set up for the CMS. The wave height, the fore-slope, the crest width, and the crest freeboard of the breakwater are listed in Table 2, which are the parameters used to determine the wave transmission coefficient for permeable breakwaters in d'Angremond et al. (1996) method.

Table 3 shows the wave height comparisons for regular wave simulations at five wave gages (WGs 3-7) selected along the channel, WGs 3-5 in the seaward zone and WGs 7-8 in the leeward zone. Overall, the laboratory and the CMS results have a good agreement and the CMS well simulates wave transmission through the permeable structure. However, the laboratory results show increasing wave heights approaching the structure in the seaward side, which are probably due to partial standing waves generated in front of the 
structure by wave reflection and are not reproduced by the CMS.

\section{Results and discussion}

\subsection{Waves and hydrodynamics}

The CMS was set up to simulate the period of 18 November17 December, 2009, which covers the initial 7 days of wave and water surface elevation data collection at the outside ADCP location and overlaps with most of the current collection period at the inside ADCP location. The permeability of the breakwaters was specified with a porosity value of 0.2 and a rock diameter of $1.5 \mathrm{~m}$. The model results were compared with the available measurements at the two ADCP sites.

Figure 7 shows the comparisons of wave parameters between the CMS calculations and ADCP data. On the ocean side, the significant wave height has a 6-day mean value of 0.75 and $0.80 \mathrm{~m}$, respectively, for the CMS results and the observations. The mean peak wave period is 13.5 and $13.1 \mathrm{~s}$, respectively. Both the CMS and data show that the wave directions are from west-southwest, perpendicular to the breakwater.

Waves approaching nearshore experience diffraction, refraction, and reflection from structures, and interact with current, wind and water level. Sensitivity tests were conducted to examine wave propagation mechanisms and wave forcing. It is found that exclusion of the wind and water level forcing in the simulations under-predicts the wave height by
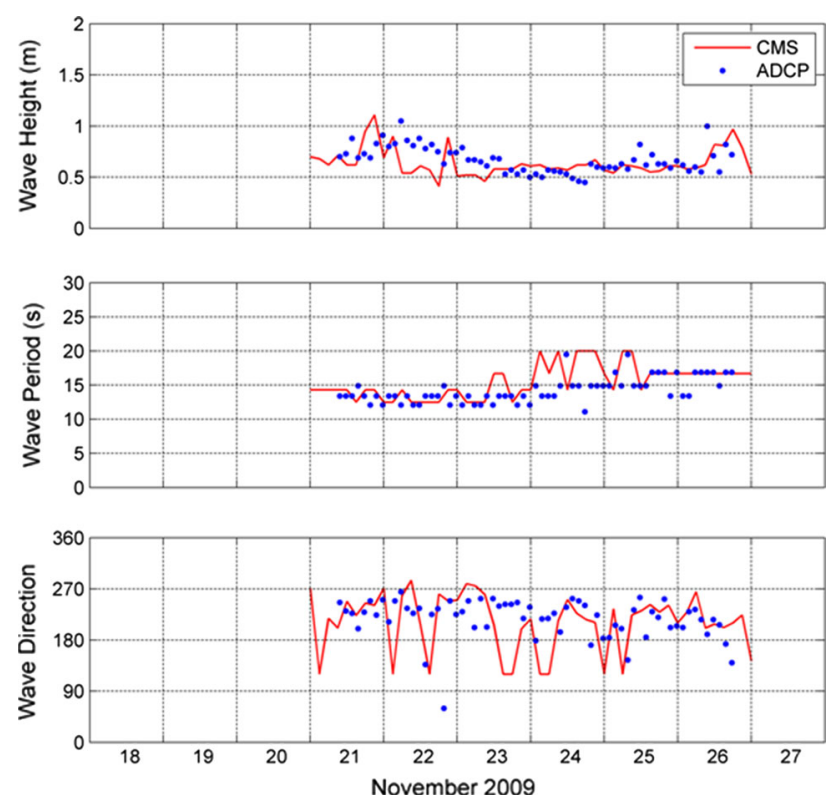

Fig. 7 Comparisons of wave parameters between calculations and measurements at the ADCP site outside the West Breakwater approximately 4-6\%, respectively. Without invoking wave reflection at the breakwater, the CMS under-predicts the wave height by as much as $31 \%$. Therefore, in the wave modeling practice near coastal structures, the focus should be on the proper parameterization and implementation of wave reflection to improve the discrepancy between the calculated and measured wave heights as compared in Fig. 7 (Lu et al. 2014).

Figure 8 shows the calculated currents and measurements at the inside ADCP location and the calculated currents at the outside ADCP location for the 30-day simulation from 18 November through 17 December 2009. Different flow patterns were exhibited at the two locations.

Two northwest winter storms occurring between 27-28 November and 7-8 December, 2009 caused high currents outside the harbor with a maximum current speed close to 50 $\mathrm{cm} / \mathrm{s}$ at the outside ADCP gage. Under normal tidal conditions the current speed at the location has a magnitude of $5-10 \mathrm{~cm} / \mathrm{s}$ with a dominant current direction from westnorthwest (along the West Breakwater) toward southeast. Inside the breakwater the current speed is generally smaller than $4 \mathrm{~cm} / \mathrm{s}$, with distinguished flood and ebb tidal current signals. A larger current spike of $8 \mathrm{~cm} / \mathrm{s}$ occurred around $7-8$ December, 2009, during the winter storm. Besides wave and wind forcing, tide is also responsible for current changes, as demonstrated by the spring/neap tidal pattern at the inside gage. Comparing to the ADCP data, the CMS well reproduced the tide- and storm-induced currents at the inside ADCP location. The goodness-of-fit parameters indicate an agreement between model and data by a correlation coefficient of 0.73 , a root mean square error (RMSE) of $1.1 \mathrm{~cm} / \mathrm{s}$, and a relative RMSE of $9.2 \%$.

Figure 9 shows a snapshot of the depth-averaged current fields on 20 November 2009 at 08:00 GMT, with relatively large waves propagating from southwest (230 azimuth). Strong currents occur near the landward end of the West Breakwater outside the harbor. The maximum current speed is approximately $50-70 \mathrm{~cm} / \mathrm{s}$. Inside the harbor, the current is weak with a maximum speed of $3-4 \mathrm{~cm} / \mathrm{s}$ over the simulation period.

Figure 10 shows the comparison of calculated and measured WSEs at the outside ADCP site for 18-27 November 2009. During this neap tidal period, the WSE change and current magnitude are small (Figs. 4, 8, 9). The CMS results agree with the WSE signals in the 6-day measurements. The goodness-of-fit parameters indicate an agreement between model and data by a correlation coefficient of 0.99 , a RMSE of $5.3 \mathrm{~cm} / \mathrm{s}$, and a relative RMSE of $4.0 \%$.

\subsection{Wave transmission, and flow seepage through breakwater}

A previous harbor survey indicated that circulation inside the Dana Point Harbor is influenced by transmitted waves 


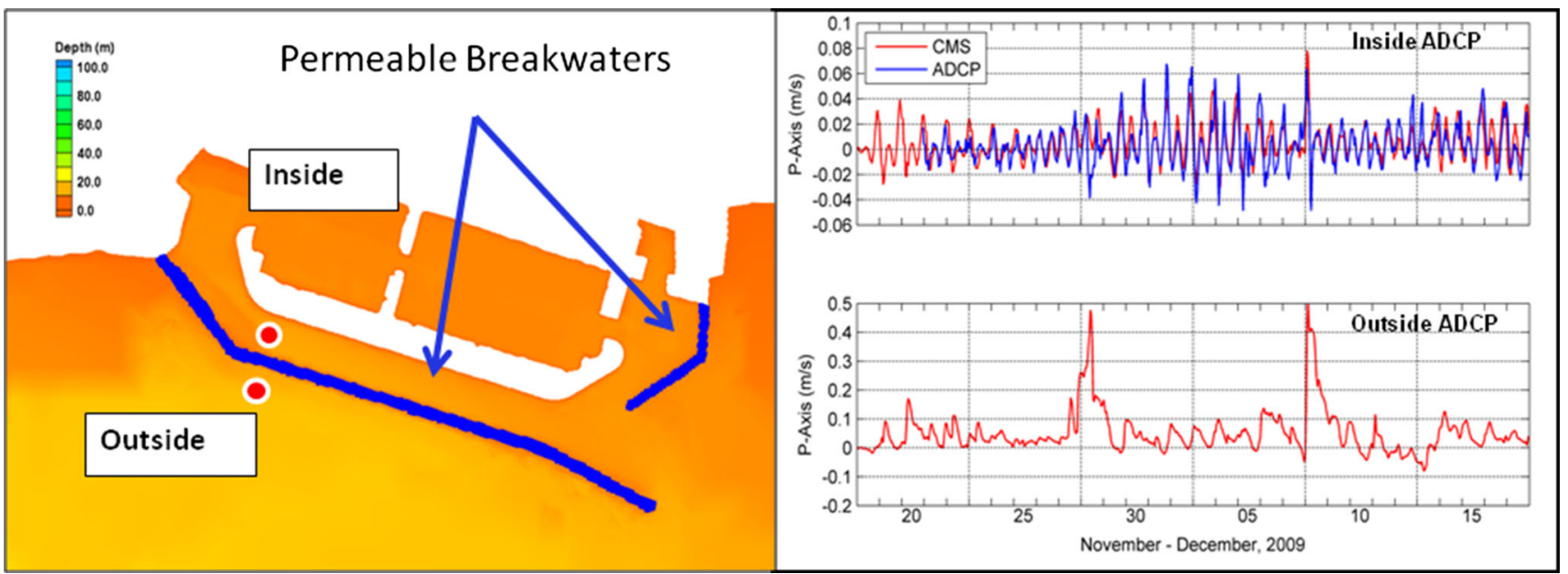

Fig. 8 Comparisons of currents between calculations and measurements at the ADCP site inside the West Breakwater

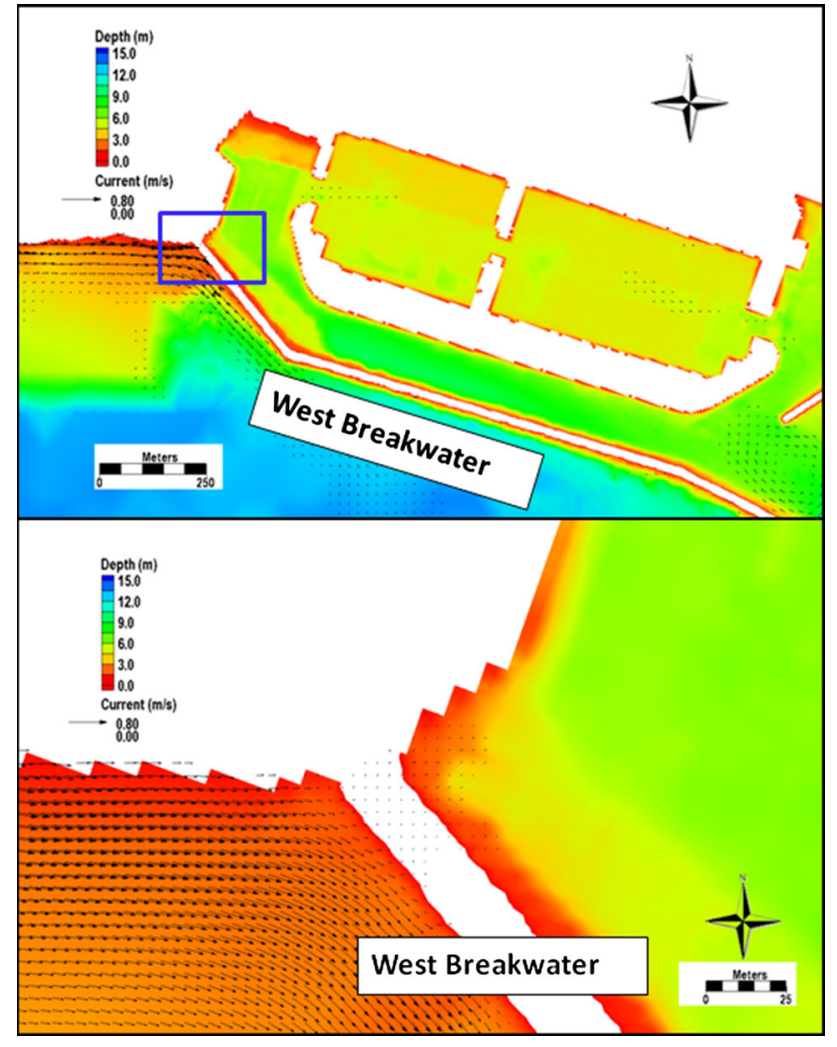

Fig. 9 CMS calculated depth-averaged current field surrounding Dana Point Harbor on 20 November 2009 at 08:00 GMT

through the West Breakwater (SAIC 2003). The Google Earth photograph taken in April 2005 (Fig. 11) shows evident sediment accumulation on the harbor side of the breakwater before a maintenance dredge took place. As mentioned earlier, the observed average annual sand deposition rate is approximately 2676 and $4129 \mathrm{~m}^{3} /$ year (3500 and 5400 cy/year) based on the maintenance dredging record in 2000

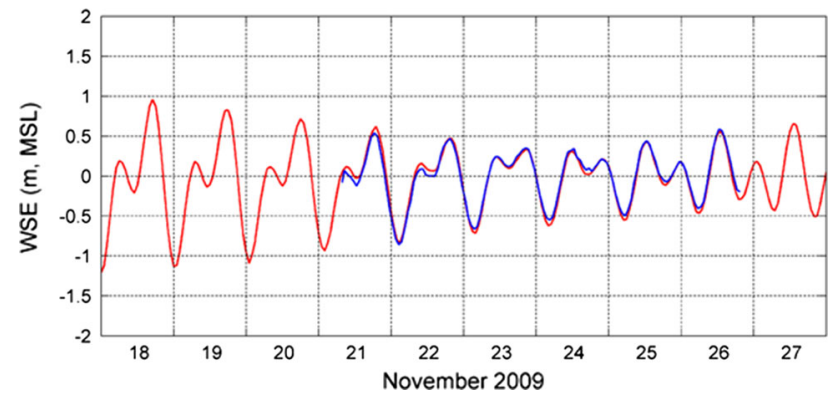

Fig. 10 Comparisons of water surface elevations between calculations and measurements at the ADCP site outside the West Breakwater

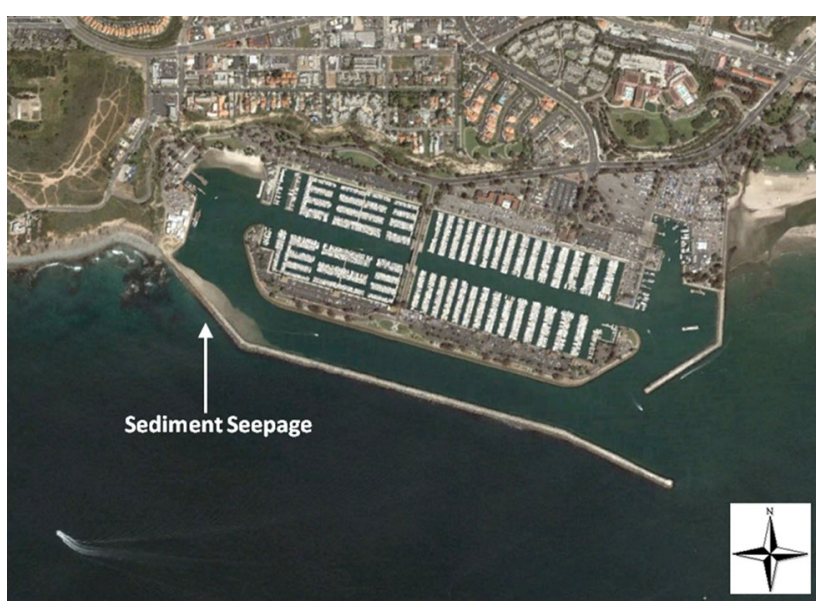

Fig. 11 Google Earth photograph of Dana Point Harbor taken in April 2005

and the latest dredging event conducted in the early 2009, respectively.

As mentioned earlier, d'Angremond et al. (1996) method is used in the CMS to calculate wave transmission through the breakwater. On average, the breakwater crest elevation is $3.4-4.6 \mathrm{~m}$ above MSL. The crest width is approximately 


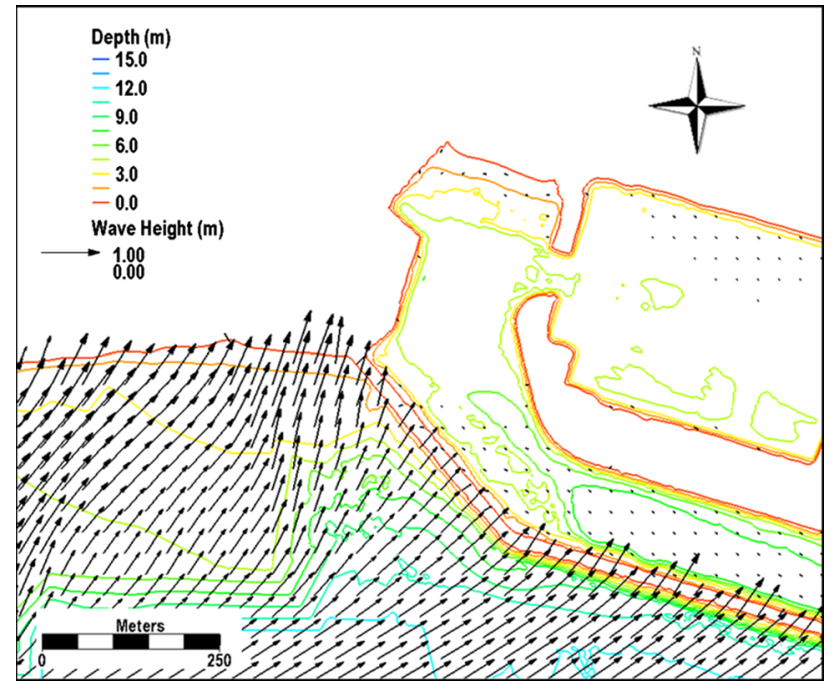

Fig. 12 Calculated significant wave height field on 20 November 2009 at 09:00 GMT

$4.5 \mathrm{~m}$ and the side slope is $2: 3$. Wave overtopping is not calculated in the simulation as it is assumed to be negligibly small for the high-crested breakwater in Dana Point Harbor.

Figure 12 shows a snapshot of calculated significant wave height field on 20 November 2009 at 09:00 GMT. Waves on the ocean side propagate perpendicular to the breakwater with a significant height of $0.6-0.7 \mathrm{~m}$. After transmitting through the structure, significant wave heights reduce to 0.05-0.07 $\mathrm{m}$ on the harbor side. Figure 9a, b show the landward end area of the West Breakwater where currents are seeping through the breakwater with a seepage rate of 2 $5 \mathrm{~cm} / \mathrm{s}$. A sensitivity run with zero structure permeability was also set up to examine waves and current on the harbor side. Comparing to the previous results with structure permeability, significant wave heights and current speeds have a value of $0.03-0.04 \mathrm{~m}$ and $0.2-0.6 \mathrm{~cm} / \mathrm{s}$, respectively, and both are directed to the southeast along the breakwater. No correlations are shown between waves and currents inside and outside the breakwater, and no wave diffraction is detected.

By varying the porosity of the breakwater from 0.2 to 0.4 and the rock diameter of 1.5 and $2.0 \mathrm{~m}$ (a 1.5 -m diameter rock is approximately equivalent to a 6-ton riprap stone), a 10-day sensitivity test was conducted for examining changes in sediment seepage through the breakwater and sedimentation in the navigational channel in response to breakwater parameter changes. The sediment transport rates shown in Table 4 indicate that as the structure porosity or the diameter of rock size increases the potential sediment seepage through the structure increases. However, proper representation of structure porosity in the simulations may not reproduce the correct amount of sediment seepage through a structure. This is because some very complex interactions occurring between
Table 4 Comparisons of calculated 10-day sediment seepage $\left(\mathrm{m}^{3}\right)$ in relation to structure porosity and rock size $(\mathrm{m})$ in diameter

\begin{tabular}{lll}
\hline Porosity & \multicolumn{2}{l}{ Rock size $(\mathrm{m})$} \\
\cline { 2 - 3 } & 1.5 & 2.0 \\
\hline 0.2 & 127 & 143 \\
0.4 & 129 & 148 \\
\hline
\end{tabular}

waves, currents and sediments within the structure are not considered in the CMS.

Wave energy transmitting and currents seeping through the permeable breakwater can push sediments into the harbor. To properly represent the structure permeability and obtain an annual sediment rate close to the structure, a 1-year simulation was conducted from November 18, 2009 to November 17, 2010. In this CMS setup the flow resistance coefficients $a$ and $b$ in Eq. (1) were determined by specifying the porosity of the medium, $n=0.2$, and the particle (rock size) diameter, $D=1.5 \mathrm{~m}$, in Eqs. (8) and (9) (Sidiropoulou et al. 2007) based on the above 10-day sensitivity simulations. The annual sediment accumulation rate was estimated using annual morphology and bed volume changes within the harbor.

Figure 13 shows the distribution of morphology change at the end of the 1-year simulation. It can be seen that significant sediment movement occurred in the west of the West Breakwater. As predominant and large waves that impact the harbor area mostly propagate from the west-northwest (Fig. 6), the longshore current and, therefore, the corresponding sediment transport are moving from the west to the east along the shoreline and from the northwest to the southeast along the West Breakwater. Four two-hourly snapshots of sediment transport are shown in Fig. 14 as relatively large waves occur in the area (significant wave height around $1.3 \mathrm{~m}$ ). Chia-Chi Lu (personal communication, 22 December 2010) indicated that significant beach erosion occurs on the west side of Dana Point during winter time. Although this model application does not include sand influx due to the beach erosion on the west open boundary, large erosion occurring around Dana Point demonstrates that sediment accreted around the harbor could be due to the Dana Point headland erosion or supplied by the sand material from the beach erosion from the west side of the headland.

As described earlier (Fig. 3), the transition between the field survey and the GEODAS datasets could create a sudden shoaling in the west side of the West Breakwater. However, Google images have shown natural outcrops and confirmed that the existence of the shallow area is a result of the headland feature, extending into the nearshore zone. Increased alongshore current results in enhanced erosion and sediment movement in the area surrounding the deposition hotspot (Figs. 9, 14), and sharp depth gradients are the primary reason for the large deposition next to the West Breakwater. 
Fig. 13 Morphology changes at the end of the 1-year (18 November 2009-17 November 2010) simulation. Annual sediment seepage rate is estimated from the bed volume changes within the polygon area delineated by the blue line. The red dot is the location where time series of depth change was plotted
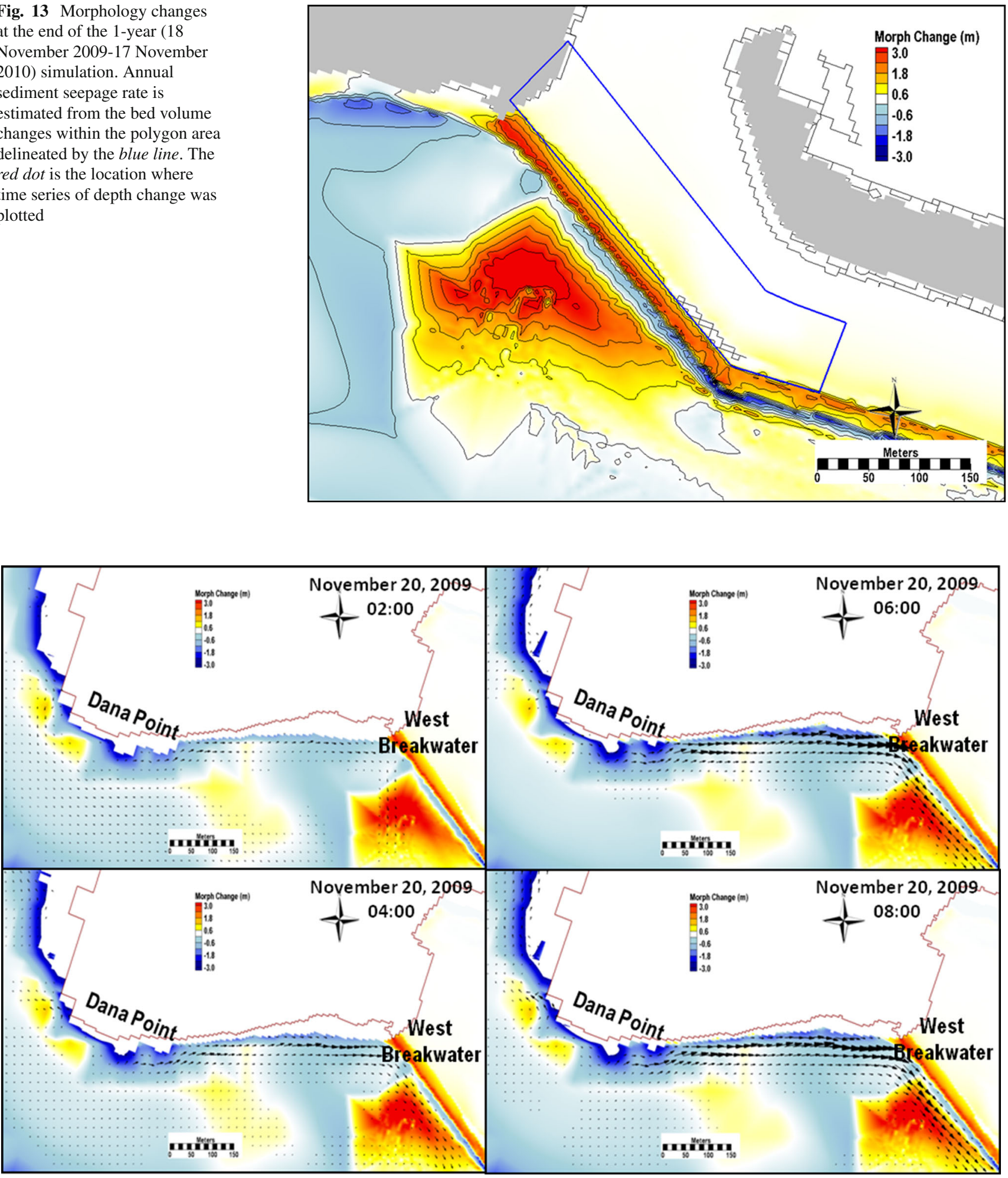

Fig. 14 Two-hourly snapshots of sediment transport (vectors) as relatively large waves occurred in the area (significant wave height around $1.3 \mathrm{~m}$ ). The background color is the morphology changes at the end of the 1-year (18 November 2009 -17 November 2010) simulation

The calculated morphology changes indicate $0.7-0.8 \mathrm{~m}$ of sediment accumulation inside the harbor along the West Breakwater. Sediment transport within structure cells is small because of lower wave energy, weaker wave-induced currents, and smaller bed shear stress available to move sediment. As a result, large deposition occurs within the 
breakwater. After seeping through the breakwater sand tends to be hugging it within the harbor due to reduced flows and diffracted waves. The distribution pattern of the morphology change is similar to the sand seepage shown in the Google Earth photograph (Fig. 11).

A polygon is drawn by the breakwater inside the harbor on Fig. 13, within which the morphology and total bed volume change were calculated at the end of the simulation. The CMS results show an annual sediment deposition rate of 2600 $\mathrm{m}^{3} /$ year (3400 cy/year) in the lee of the West Breakwater, which is quantitatively comparable to the average annual volume dredged in 2000 , but significantly less than that dredged in 2009.

In an attempt to increase the annual seepage rate, the 1year simulation was rerun with $D=2 \mathrm{~m}$. However, the results did not show much improvement. Temporal changes of depth at a location inside the harbor reveal that sediment has a rapid accumulation rate in the first 2 months, especially corresponding to four storm events, and reaches the equilibrium state after 5 months of the simulation (Fig. 15). For a longer term simulation, the sediment seepage rate through a structure would not change significantly in response to the change in porosity parameters once an equilibrium state between sediment seepage and structure storage capacity has been reached.

The difference in sediment accumulation between the dredging volumes and model results are caused by: (1) not properly represented structure porosity properties in the transport equations, (2) lack of the more detail dredge information (e.g., covered areas of dredging operations not overlapping with the polygon area in Fig. 13), and (3) lack of information on fine material brought into the navigation channel by the drainage system.
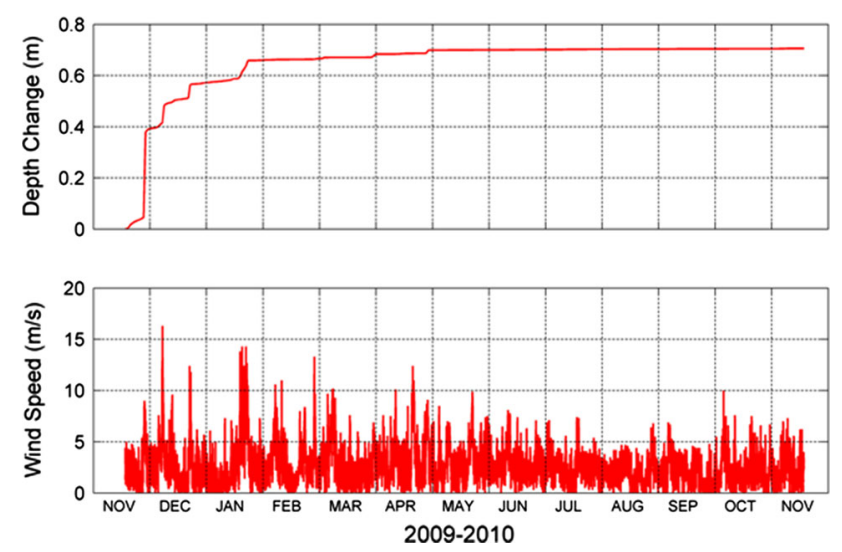

Fig. 15 Depth change at the location inside the West Breakwater (Fig. 13) and wind speed at the coastal gage, NOAA La Jolla gage (9410230), 18 November, 2009-17 November, 2010

\section{Conclusions}

Sediment seepage through a permeable breakwater was simulated by the CMS, an integrated wave, flow and sediment transport modeling system. The model performance was investigated by comparing to the measured waves, current, and water surface elevation at two ADCP locations and to a laboratory experiment. The implementation of the algorithms for flow seepage and sediment transport was validated by historical dredging information.

Comparisons of the CMS results and ADCP data indicate that waves are the dominant forcing outside the West Breakwater at Dana Point Harbor. Inside the harbor, currents are mainly wind- and tide-driven with small current magnitude of less than $4 \mathrm{~cm} / \mathrm{s}$. The depth-averaged current has a speed of greater than $10 \mathrm{~cm} / \mathrm{s}$ outside the harbor and can reach more than $50 \mathrm{~cm} / \mathrm{s}$ under storm condition.

Wave transmission is implemented in the CMS by calculating a transmission coefficient. The CMS results demonstrate the model's capability in reproducing wave propagation through an emerged structure. The permeability of rubble-mound breakwaters is specified in the CMS by adding a flow resistance term in the momentum equations and considering void space in the mass balance equation. The breakwater porosity and the diameter of riprap stones can be adjusted to obtain different amount of sediment transport through the semi-permeable breakwaters. The calculated annual sediment transport rate was compared against the sediment volume accumulation inside the harbor based on the historical maintenance dredging data. Modeling estimates were insensitive to parameters investigated once an equilibrium state was reached between sediment seepage and structure storage capacity.

It is noted that the parameters $a$ and $b$ do not include the added resistance due to wave-induced motions in the breakwater, and previous approaches applied to wave and flow interaction with porous structures only address the hydrodynamic dissipation and none of them directly address sediment transport processes in the breakwater. Future model development should include the wave-induced resistance terms in porous breakwaters (Muttray and Oumeraci 2005). Intuitively, the wave-induced motion will not only increase the resistance to the mean (wave-averaged) flow through the breakwater, but also increases the sediment mobility within the breakwater. These two effects would likely contribute to the differences between the measured and simulated transport volumes.

Acknowledgments The authors are grateful to County of Orange and City of Dana Point, California, for providing maintenance dredging data and field observations of sedimentation and water circulation in Dana Point Harbor. Special thanks to Dr. Julie D. Rosati for her continual support and encouragement towards development and improvement of 
the CMS. Permission was granted by the Office, Chief of Engineers, US Army Corps of Engineers to publish this work.

\section{References}

Aquaveo (2010) SMS: XY series files (*.xys). http://www.xmswiki.com/xms/SMS:XY_Series_Files_(*.xys). Accessed 27 Mar 2015

Buttolph AM, Reed CW, Kraus NC, Ono N, Larson M, Camenen B, Hanson H, Wamsley T, Zundel AK (2006) Two-dimensional depthaveraged circulation model CMS-M2-D: version 3.0, report 2, sediment transport and morphology change. Coastal and Hydraulics Laboratory Technical Report ERDC/CHL-TR-06-7. US Army Engineer Research and Development Center, Vicksburg

California Coastal Commission (1999) Permit application for maintenance dredging at Dana Point Harbor. Application No. cc-138-97

California Coastal Commission (2008) Permit application for maintenance dredging at Dana Point Harbor. Application No. 5-06-458

County of Orange (1990) Plans and special provisions for the maintenance dredging at Dana Point Harbor, funded by Department of Harbor, Beaches and Parks, County of Orange. California, W.O. H08210

d'Angremond K, Van der Meer JW, de Jong RJ (1996) Wave transmission at low-crested structures. In: Proceedings of 25 th international conference on coastal engineering, Orlando. ASCE, pp 2418-2427

Forchheimer PH (1901) Wasserbewegung durch Boden. Zeitschrift des Vereines Deutscher Ingenieure 50:1781-1788

Fugro West (2010) US Army Corps of Engineers Dana Point Harbor Breakwater Comprehensive Condition Survey. Field Operation Report 1230.018R2.0. Fugro West Inc, Ventura

Garcia N, Lara JL, Losada IJ (2004) 2-D numerical analysis of near-field flow at low-crested permeable breakwaters. Coast Eng 51:9911020

Kadlec HR, Knight LR (1996) Treatment wetlands. Lewis Publishers, London

Lara JL, Garcia N, Losada IJ (2006) RANS modeling applied to random wave interaction with submerged permeable structures. Coast Eng $53: 395-417$

Li H, Lin L, Lu C, Shak AT (2011) Evaluation of breakwaters and sedimentation at Dana Point Harbor, CA. In: Proceedings of coastal sediments 2011, Miami, vol 3, pp 2585-2598

Lin L, Demirbilek Z, Mase H (2009) Recent capabilities of CMS-wave: a coastal wave model for inlets and navigation projects. In: Roberts TM, Rosati JD, Wang P (eds) Proceedings, symposium to honor Dr. Nicholas C. Kraus, Journal of Coastal Research, special isssue, vol 59, pp 7-14. West Palm Beach (Florida), ISSN 0749-0208

Lin L, Demirbilek Z, Thomas R, Rosati J III (2011) Verification and validation of the Coastal Modeling System, report 2: CMS-Wave. Coastal and Hydraulics Laboratory Technical Report ERDC/CHLTR-11-10. US Army Engineer Research and Development Center, Vicksburg
Lu C, Shak AT, Li H, Lin L (2014) Comprehensive condition survey and storm waves, circulation, and sedimentation study, Dana Point Harbor, CA. Coastal and Hydraulics Laboratory Technical Report ERDC/CHL-TR-14-13. US Army Engineer Research and Development Center, Vicksburg

Muttray MO, Oumeraci H (2005) Theoretical and experimental study on wave damping inside a rubble mound breakwater. Coast Eng 52:709-725

National Geophysical Data Center (2009) Bathymetry, topography and relief. http://www.ngdc.noaa.gov/mgg/bathymetry/relief. html. Accessed 27 Mar 2015

SAIC (2003) Circulation Study Report Baby Beach Region, Dana Point Harbor, California. Prepared for County of Orange, Public Facilities and Resources Department. Science Application International Corporation, Environmental Sciences Division, San Diego

Sanchez A, Wu W, Beck TM, Li H, Rosati JD, Demirbilek Z, Brown M (2011a) Verification and validation of the Coastal Modeling System, report 4: sediment transport and morphology change. Coastal and Hydraulics Laboratory Technical Report ERDC/CHLTR-11-10. US Army Engineer Research and Development Center, Vicksburg

Sanchez A, Wu W, Beck TM, Li H, Rosati J III, Thomas R, Rosati JD, Demirbilek Z, Brown M, Reed C (2011b) Verification and validation of the Coastal Modeling System, report 3: hydrodynamics. Coastal and Hydraulics Laboratory Technical Report ERDC/CHLTR-11-10. US Army Engineer Research and Development Center, Vicksburg

Sidiropoulou MG, Moutsopoulos KN, Tsihrintzis VA (2007) Determination of Forchheimer equation coefficients $a$ and $b$. Hydrol Process 21(4):534-554

Simpson DP, Rosati JD, Hales LZ, Denes TA, Thomas JL (1990) Rehabilitation of permeable breakwaters and jetties by void sealing: summary report. Technical Report REMR-CO-16. US Army Engineer Waterways Experiment Station, Vicksburg

TM 5-622/MO-104/AFM 91-34 (1978) Maintenance of waterfront facilities. Technical Manual (ARMY TM-5-622; NAVY MO-104; AIR FORCE AFM 91-34). Department of the Army, the Navy and the Air Force

Tsai CP, Chen HB, Lee FC (2006) Wave transformation over submerged permeable breakwater on porous bottom. Ocean Eng 33:16231643

USACE-LAD (1991) Comprehensive condition survey, Dana Point Harbor. Final report, December 1991. US Army Engineer Los Angeles District, Los Angeles

Ward JC (1964) Turbulent Flow in porous media. J Hydraul Div ASCE 90(5):1-12 